\title{
Ethnoscience A Bridge To Back To Nature
}

\author{
Heddy S. A. Putra ${ }^{1 *}$ \\ ${ }^{1}$ Faculty of Humanities, Department of Anthropology, Gajah Mada University, Yogyakarta, Indonesia
}

\begin{abstract}
Ethnoscience is a paradigm emerged in anthropology in mid-1950s, as a further result of the attempts made by some American anthropologists to redefine the concept of culture that will be in line with the new model they adopt for their study and description of culture that is descriptive phonology. For ethnoscientists culture is not a material or behavioural phenomenon. It is an ideational phenomenon. In Goode-nough's word, "culture is not a material phenomenon; it does not consist of things, people, behavior or emotions. It is rather the organization of these things. It is the forms of things that people have in mind, their models for perceiving, relating and otherwise interpreting them as such.." (1964: 36). Culture is thus a system of knowledge. The culture of a people is their ethnoscience (ethnos = people; scientia $=$ knowledge). Since culture is a very broad category, no anthropologist can do research on a peo-ple's culture as a whole. He can only investigate and describe some parts of it. Thus, Harold Conklin (1954) focussed his research among the Hanunoo in the Phillippines on their knowledge about their environment, or their ethnoecology. Even then, ethnoecology is still a very broad category, for it encompasses flora, fauna and other material inanimate objects. Later ethnoscience researchers pay their attention to smaller parts of the phenomena. Several branches of study then sprouted from ethnoecology, focussing on some elements the environment, such as ethnozoology, ethnobotany, ethnoastronomy, ethnopedology, etc. From ethnozoology, new branches of study -narrower in scope- appeared, such as ethnoornithology, etnoichtyology, ethnoherpetology. These bran-ches show how the attentions of the researchers go deeper and deeper to the tiny details of the environment, of the nature, and how the people view, give meaning and relate themselves to them. These studies show that ethnoscience has helped humans to gain better understandings of and their relations to the nature. It is in this sense that ethnoscience has become a bridge to go "back to nature".
\end{abstract}

\section{Introduction}

Ethnoscience is not a very popular name for a paradigm in social science, although it is now about 70 years old. It emerged in American anthropology in 1950s, becoming very popular in 1960 s, declined in popularity in 1970s afterwards, but of course not in its influence on other disciplines, which -interestingly enough- are not social but natural sciences, especially biology. Although Keesing (1970) predicted that the paradigm would disappear due to the transformations in linguistics, a discipline that had become a model for ethnoscience. It turned out, however, that changes in linguistics did not have much impact on ethnoscience. Many anthropologists did believe in ethnoscience strong foundations, methods, as well as its benefits for the people they studied when it is used in research and its results were applied in development projects

Ethnoscience appeared and developed in anthropology not through a well-defined plan, nor a conscious effort to build a new paradigm, but from an awareness of a se-rious problem faced by anthropology in its way to become a science of culture that can produce generalizations or law-like generalizations about cultural phenomena, namely the comparability of its data. Comparative study of cultures -known as crosscultural comparison- is the method that anthropologists should adopt if they want to produce strong generalizations of cultural phenomena [46]. Unfortunately, the ethnographies produced by anthropologists vary in their content as well as the way they were written.

The variations in content are the result of several factors [4]. First, is the different interest of the anthropologists in their research. Anthropologist with a great interest in kinship would naturally write a kinship system of the people (s)he study in great detail, while their rituals and their laws are probably not touched. Other anthropologist interested in economic system would describe a lot of things about this system, while the arts of the people are not given enough attention. Their ethnogra-phies would be very different from one another. This creates difficulty for anthropolo-gists attempting to reach generalizations through comparative study based on those ethnographies, because the data are not comparable.

Secondly, anthropologists may use different paradigms in doing research on the same topics. One anthropologist prefers to use evolutionary perspective in his research on the economic and political system of a certain people, while other anthropologist chooses to use functional approach in his analysis and description of those systems. The ethnographies they produced could not then be easily used by other anthropo-logists for

\footnotetext{
* Corresponding author: heddy.shri@ugm.ac.id
} 
comparative study, for the data are not quite comparable.

Thirdly, even when anthropologists study the same topic using the same concept, they may give different meaning to the concept, that they interpret the findings differ-rently, and draw different conclusions. This creates difficulty in comparative study that will use their findings.

Variations in ethnographical data, in their interpretations and in the conclusions of the analyses created a serious problem in anthropology which main goal is among others to produce generalizations about socio-cultural phenomena through cross-cultu-ral comparison. As Tyler (1969) has said, “...Comparison between systems can only be useful if the facts compared are truly comparable, and we cannot know what facts are compa-rable until the facts themselves are adequately described".

This problem made some anthropologists rethink the way they write their ethnogra-phies and thus their conception of culture. Since some anthropologists are familiar with linguistics, it is not surprising if they looked at linguistics to get some inspirations in how to describe culture, so that its descriptions, the ethnographies, are comparable to one another [20, 35, 36].

\section{The Emergence of Ethnoscience}

The word ethnoscience came from a Greek word, ethnos, and a Latin word, scien-tia, knowledge [95]. Thus, ethnoscience is the knowledge of an ethnic group, or a system of knowledge and cognition typical of given culture [86]. Etnoscience in this case is not a research method, nor is it a paradigm. However, in its development, its practitioners have to deal with methodolo-gical problems as well as the theoretical foundations of their research. This had trans-formed ethnoscience as field of research into a research paradigm $[92,93,94]$.

The use of descriptive phonology as a model for cultural description made anthropo-logists realize that their definition of culture does not really match with that model. A new conception of culture was thus needed, and Goodenough proposed one. In phono-logy a phonetic writing is basically a description of how one should pronounce a cer-tain word so that a language learner can pronounce the word correctly, and can communicate with native speaker smoothly. It means that it is a description of what one has to do in order to produce certain sounds orally or with their mouth. From that point of view, a description of culture then is a description of "whatever it is one has to know or believe in order to operate in a manner acceptable to its members, and do so in any role that they accept for any one of themselves. Culture, being what people have to learn as distinct from their biological heritage must consist of the end product of learning: knowledge" [35]. Therefore, "culture is not a material phenome-non; it does not consist of things, people, behavior or emotions. It is rather the organization of these things. It is the forms of things that people have in mind, their models for perceiving, relating and otherwise interpreting them as such. The things that people say and do, their social arrangement and events are products or by products of their culture as they apply it to the task of perceiving and dealing with their circum-stances." [37].

The view of culture as an ideational phenomenon was then developed further by other anthropologists, such as Charles O.Frake, who defined culture as "a set of principles for creating dramas, for writing scripts, and of course, for recruit-ing players and audience. Culture is not simply a cognitive map that people acquire, in whole or in part, more or less accurately, and then learn to read. People are not just map-readers; they are mapmakers. Culture does not provide a cognitive map, but rather a set of principles for map making and navigation. Different cultures are like dif-ferent schools of navigation designed to cope with different terrain and seas" [31].

The adoption of descriptive phonology as a model for cultural description and the new definition of culture create a new need for cultural description that would really re-flect these new ideas. This led anthropologists to adopt a new style of ethnography which will be able to represent the cognition of the people.

In addition to the new definition of culture, anthropologists thought further about its implications, since a new definition of the object of a study would of course give new direction to researches to be conducted and ethnographies to be produced. The des-cription of culture for instance would then focus on the "cognitive organizations of mate-rial phenomena", therefore "cultures are neither described by mere arbitrarily lists of anatomical traits and institutions such as house type, family type, kinship type, economic type, and personality type, nor are they necessarily equated with some over-all integrative pattern of these phenomena" [88].

Furthermore, each culture does not only organize the material phenomena but also other kinds of phenomena, in its own distinctive way. As Tyler has put it, "Not only do cultures differ among one another in the kinds of material phenomena they organize. The people of different cultures may not recognize the same kinds of material phenomena as relevant, even though from an outsider's point of view the same materi-al phenomena may be present in every case..." [88].

In addition to that, in a particular culture, the same phenomena can also be orga-nized cognitively in various ways, from which intracultural variations arise. Of course, for some people "Some intracultural variations may be idiosyncratic, but more impor-tant from the anthropologist's point of view are those variations which are used by different classes of people and/or occur in different situations and contexts [35, 88]. These variations are important for researchers, since they are in many cases are related to classes, groups, social strata, and their social and cultural situations and conditions. In short, the idea of culture as ideational phenomenon made anthropologists more aware of its intra- and intercultural variations. Culture then is not a singular, homogenous phenomenon.

From the new conception of culture, several strands of studies emerged. First is the study that pays more 
attention to "..the forms of things that people have in mind, their models for perceiving.." [35] which in this case is interpreted as models for classifying the social, the cultural and the environmental phenomena. Ethnoscience research here attempts to uncover the empirical aspects of the phenomena considered important by members of a culture and how they organized them in their knowledge system. These will show the principles they used to understand their environment on which their behaviour based [88]. Each society, community or social group basically has different classification system of the same environmental elements. Knowledge of their various categorizations of their environment will give researcher understanding the people's cognitive map of their environment [31].

Second, is the study that focused on "whatever it is one has to know or believe in order to operate in a manner acceptable to its members, and do so in any role that they accept for any one of themselves" [35]. The aim is to describe the rules in some parts of social life, including the social categories governed by those rules in their social interactions.

Thirdly, ethnoscientific study starts from the idea that culture is a system of know-ledge used "to the task of perceiving and dealing with their circumstances.." or know-ledge to be used in the interpretation, in the understanding of various phenomena and how to deal with them properly. The aim of the researcher here is to elucidate the meanings, values, that the people assign to the elements of their environment, from which cultural themes are derived [83]

Here, some other researchers put more emphasis on the content of the people's knowledge, i.e. their system of classification, such as mentioned by Perchonock dan Werner (1969),. They said that "Ethnoscience is concerned solely with classifica-tion principles as they are expressed by native speakers of the languages, not as they are determined through anthropological observation. Ethnoscientists are interested in the native's knowledge of the various domains within their culture, instead of their ac-tual behavior in these domains.

Until early 2000s there were at least those three kinds of Ethnoscientific researches. Each was started from or based on a certain part of the definition of culture as a know-ledge system. Ethnoscience is thus interpreted as a theoretical framework or paradigm which primary goal is to uncover, to delineate, a people's system of knowledge. This line of thought was popular among the American anthropologists in 19601970s.

Starting from those three variants, ethnoscientific studies today cover wider range of phenomena and problems. A society's system of knowledge is a very broad category that an anthropologist cannot study it thoroughly, in all its aspects and elements, let alone the knowledge of an ethnic group. In addition to that, he may not be interested in all content of that knowledge. An ethnoscientific researcher would thus limit his study on certain parts of that knowledge. It is from these specific fields of studies that new kinds of ethnoscience appear such as ethnoecology, ethnobotany, ethnozoology, eth-nomedicine, ethnopharmacology, etc.

Ethnoscience as a new way of investigating, analysing and describing a culture was then applied by anthropologists, especially American anthropologists, in various fields of culture such. The prefix "ethno-" with its various dimensions of meaning, and its practicality, enabled anthropologists to use it in investigating any field of life.

\section{From Ethnoscience to Ethnoecology}

One of the fields in which ethnoscience is applied by anthropologist is ecology. This was started by Conklin (1954) in his study of the swidden agriculture of the Hanunoo in the Phillippines. Adopting that approach known as ethnoecology- Conklin was able to uncover and describe Hanunoo's knowledge of their environmental elements relevant for their agriculture. His study was then followed by other anthropologists interested in ecology or processes of people's adaptation to their natural environment.

Research on the adaptation to the local environment was conducted for instance by Begossi (2006) among the Caicarasan, inhabiting the coastal areas of Sao Paulo and Rio de Janeiro in Brazil. The study was aimed at understanding their strategies to survive in such environment. Another study was carried out by Watts et al (2017) among the Inuit. The goal was to understand how their methods of utilizing and ma-naging living organisms of their environment, such as various fishes, see mammals, help them to find ways to solve their food problems. Another ethnoecological research among the Yucatec Maya -carried out by Barrera-Bassols and Toledo (2005)-, was aimed at uncovering the survival strategies adopt by the peoples that enable them to live in their environment for more than three thousand years. Moran and Posey (2019) investigated the ethnoecology of the Kayapa living in Amazon Basin. Their research produced a detailed description of the relationships between the Kayapa and the animals, plants and other natural resources, which reflect the complex and detailed knowledge of the Kayapa about their natural environment.

Using ethnoecological approach, anthropologists interested in agricultural societies pay much attention to the people's knowledge of various plants they cultivated. John-son (2008) for instance conducted research among the Indians in Canada, living in northern forests. He analyzed and compared various names given by the Indian to the local plants. His study showed that the local people give names to the plants and their habitats on the basis of their views and their knowledge of their environment, which is holistic and interactive. This system of classification differs significantly from scientific classification (botany and ecology).

In Indonesia, ethnoecological research was also conducted in Banyuwangi to under-stand patterns of exploiting and cultivating bamboo of which several traditional musical instruments are made [90]. In Mexico, researchers used ethnoecology in their study among the peasants of Chiapas, Mexico, to uncover the 
peasants' know-ledge of corns and their patterns of cultivation of these plants. Rangel-Landa et al (2016) carried out research among the Ixcatex, in Oaxaca, Mexico, on their manage-ment of plants, their agricultural patterns and their responses to new developments in agricultural technologies.

\section{From Ethnoecology to Ethnobiology}

Further development in ethnoecological studies show that they cover a wide range of phenomena, from the soil, to the seas, the rivers, the winds, up to the heavenly bo-dies. Thus, some researchers focus only on some elements of the environment, such as biological elements consisting of living organisms. Study of these living things using ethnoscience approach is known as ethnobiology. This field covers such a wide range of living species. The division of biology into botany and zoology is applied in ethno-biology, which led to the development of ethnobotany and ethnozoology. In this case, the branches of ethnozoology seem to develop faster than ethnobotany, although ethnobotanical researches seem to be more varied.

One of the developed fields in ethnobiology is medical ethnobiology. This kind of study was conducted for instance by Pieroni, Giusti and Quave (2011), among the Al-banian and the Serbian in Pester plateau (Southwest Serbia), on their uses of plants for medicines. These two ethnic groups arrived in the area around 300 years ago. Al-though they have been using the medicinal plants of the same quantity and the same species (two thirds of the documented plants), but only one third of these plants are used similarly.

The development of ethnozoology and ethnobotany made researchers aware that these sub-fields of ethnobiology are still very broad fields. Studies in these fields need to give attention to animals and plants living in very different habitat that researchers need to classify their studies into smaller category of fields. Thus appear aquatic ethnobiology, a new field of study paying attention to plants and animal living in the water. As Garcia-Quijano and Pitchon (2010: 1) stated, aquatic ethnobiology is "the study of the evolving interrelationships between people and aquatic organisms". This field emerged ini 1960s and developed quickly that lead some ethnobiologists to divide the field into ethnoichthyology, that is "the study of peoples interactions with large aquatic animals", and ethnophycology, that is "the study of peoples interactions with aquatic autotrophic producers, including algae and aquatic vascular plants" (2010: 1).

In ethnobotany, the influence of ethnoscience can be seen in its studies of classify-cation employed by the people in dealing with various plants in their environment. Johnson's (2008) ethnobotanical study among the Dene Indian in Canada for instance, paid attention to the Dene's classification of plants. Their plant taxonomy is different from the one in biology, since it related to their landscape. Their plant taxa are based on their ecological knowledge, which is holistic and interactive.
Research of plant classifications developed further into studies on the practices of the peoples based on their plant classification. In this case attention were be given more to the activities of the people led by their knowledge of their environment. Thus Motto, Antignani and Idolo (2009) conducted research on the uses of the plants for the people in Campania, South Italy. People use the plants not only for food but also for medicines.

Ethnobotanical researches were also conducted in India, where people have a long tradition of using plants for various needs. They have extensive knowledge of plants with their uses. Research by Begum and Nath (2000) in North-eastern India found that of 275 plants documented, 224 had been used by the people to cure various hurts and illnesses. Similar research carried out by Samant and Dhar (1997) in Himalaya moun-tain areas found that local peoples have used plants and trees to meet various daily needs, such as for food, for fire wood, for making utensils, for curing, enz. The wild consumable or edible plants become substitution of food in times of food crises. More than 675 wild plants are consumable, whether they are raw, cooked, or fried.

\section{From Ethnoecology to Ethnopedology}

Traditional agricultural activities are always related to soil, thus research on ethno-ecology in this field need to cover not only the plants but also the soil. Ethnopedology is a branch of ethnoecology, focussing on the study of soil as it is understood and given meaning by the people who live on it, and the patterns of its cultivation based on that understanding. One of the topics studied by many researchers here is the elements of soil considered important, such as its location, its kind, its characteristics. In ethnope-dology, the attempt of the researcher is "to document and increase understanding of local approaches to soil perception, classification, appraisal, use, and management" [11]

Ethnopedological research had been conducted for instance by Fritz-Vietta, Tahirin-draza and StollKleeman (2017) in southwestern Madagaskar, on Mahafaly plateau. They found that various categories of soils and their cultivations reflect local people's deep knowledge of the soils, their categories and their relations to natural and spiritual processes. These categories enable researchers to trace what factors influence the management and exploitation of the local natural resources. Trusler and Johnson (2008) carried out research among Gitksan dan Wet'su-wet'en Indian to uncover their knowledge of their land plots on which they would plant blackberry, the most important plant in their life all year long. Their knowledge is not as simple as it may seem. The selection of the plots for blackberry is based on several criteria, such biophysical characteristics -elevation, humidity-, distance to place for fishing, village, or places of other economic activities. The selection of an ideal plot to plant blackberry is done through considering the physical characteristics of the environment, as well as social and eco-nomic situations. Similar research was conducted by Pedroso-Junior and Salo (2005) in Brazil, which tried to map local 
knowledge on soil, its kind, its natural cycle, species living on it, etc. in Superagui National Park. The local knowledge was then incorporated in the management process of the Park. Ethnoecological researches show that the results are very important not only for the empowerment of the local people, but also for planning and management of the protected areas, as well as for education on envi-ronmental affairs $[73,86]$.

The development of ethnoscience into several subfields and sub-sub-fields can be presented as follows

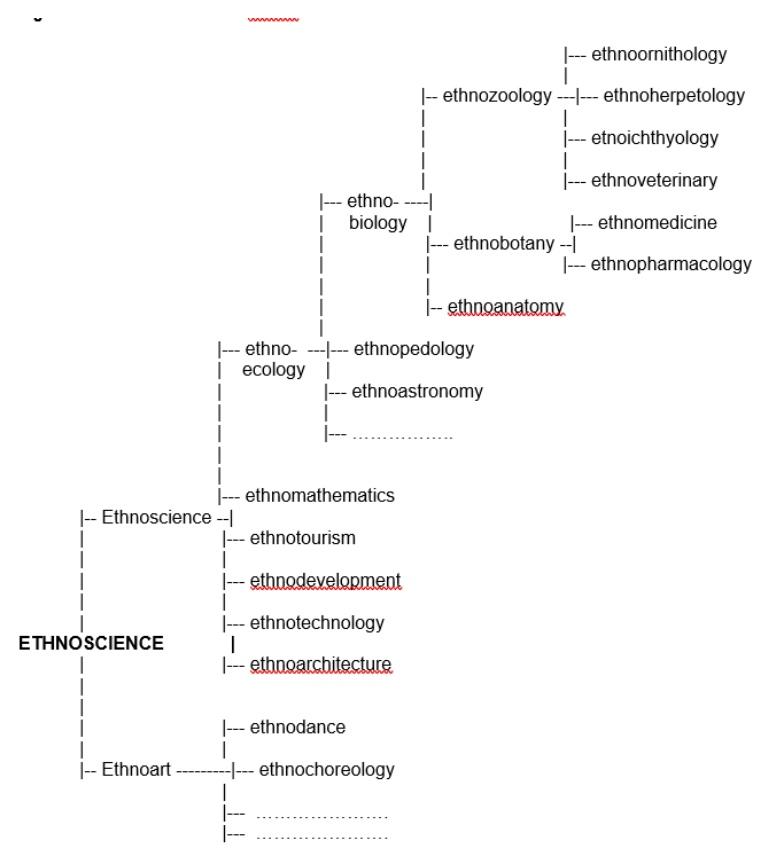

Figure 1. Branches of Ethnoscience

In the case of ethnobiology, considering its great potential to branch out, its deve-lopment in the future may lead to the emergence of other kinds of branches, if "aquatic ethnobiology" appear. This field may separate itself from non-aquatic ethnobiology, which may branch out further.

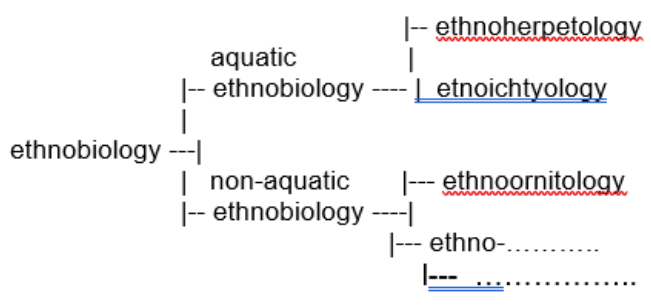

Figure 2. Branches of Ethnobiology

The diagram shows the development of an ethnoscience branch that studies envi-ronment in general or nature, namely ethnoecology. This field develops faster than other fields in ethnoscience. This is a clear indicator of the relevance of ethnoscience for any attempt to go "back-to-nature".

\section{6 "Back-to-Nature" and Ethnoscience}

What is "back-to-nature"? There are at least two meanings of "back-to-nature" rele-vant to our discussion here. First, it is a socio-cultural movement in the West emerged in 1970s, as a response to the fast process of industrialization which separate further and further human beings from their natural environment. It is "the growing complexity of modern life, the increasing pollution of food and environment, the depersonalizing effects of functioning as a "cog in a machine," and the widespread abandonment of moral and spiritual values for purely materialistic ones-" that have become reasons for the emergence of "back-tonature" movement. It constitute "a rejection of the very tech-nology which the futurists see as inevitable..." [19].

"Back-to-nature movement" may also be associated with "any effort which seeks the return to a simpler or preindustrial way of doing things" [19]. The move-ment can be seen in the rising interest of the people in the West in, and "advocacy of, such things as natural food, natural childbirth, ecology and environmental protection, communes (and particularly agricultural communes), organic farming, solar and wind power, handicrafts, hirsuteness, and social "dropping out" (p.227)

The second meaning of "back-to-nature" relates to a methodology of teaching bio-logy to students in high school. The method employed is based on the assumptions that, 1) students "are filled with wonder when experiencing the splendor of the natural"; 2) their level of appreciation for nature will grow, if they "are given the oppor tunity to observe and interact with the natural environment"; 3) "conserving the natural world will be more important to students if they are able to witness the uniqueness of the different organisms that make up different ecosystem"; 4) "students need to appreciate naturalistic biology because the rate of species extinction and habitat loss are important areas of ecological research" [76].

In this methodology, the teacher needs to develop "an activity in which students research not only the ecosystem at large but also the niche of specific species". This will lead the students "to an understanding of how important even seemingly insignifi-cant species are to their ecosystems". In groups, the students will be asked to do "a biological survey", that is conducting "naturalistic observations of their ecosystem" in which they have to "identify as many plants, animals, and fungi as possible". Then the students compare the results of their observations. (p. 62)

In the second phase, the teacher will ask the student groups to "take a more critical look at the ecosystem and apply the concepts covered in the first phase. The groups study only a square meter of the ecosystem instead of observing the ecosystem at large". The teacher will tell where student groups should set up their quadrants. "It is essential that the quadrants be assigned in a variety of locales to identify the different plants, animals, and fungi in the respective locales". This will enhance the concept of biodiversity in the ecosystem for students. The student groups are assigned to write a report on what they have observed and present it in the class [76]. 
What is the relevance of ethnoscience to the movement and the methodology? I see no direct relationship between ethnoscience, the movement and the method, but ethno-science is relevant for both in different ways. For the movement, ethnoscience gives a lot of data that can be used for achieving the goals of the movement. Ethnoscience gives information on the methods that people from various parts of the world use to get benefits from nature, without using modern technology.

As for the methodology, ethnoscience gives a lot of examples on how people have their own methods to adapt with the natural environment. They also build their own knowledge based on their "naturalistic observation of their ecosystem". Comparing a variety of methods that people use in their adaptation to their environment will enhance our understanding of diversity of human life and the biodiversity on earth.

\section{Summary}

In this paper I have shown the development of a new paradigm in anthropology, known as ethnoscience. Starting as a new field of study, focussing on people's system of knowledge, ethnoscience has now become a new paradigm for research in various fields and disciplines. It has also branched out in many directions.

The diagram on the development of ethnoscience shows several important fact. First, ethnoscientific researches had met researches in other fields, resulted in new combined sub-disciplines, one of which is ethnoecology. It is from this sub-field that other subsub-disciplines grew such as ethnozoology and ethnobotany. Thus, ethno-science has opened the door for the cooperation among scientists of different disciplines. New information on man's place in the world as well as his relationships to other living beings and various kinds of physical environments have been produced. Second-ly, ethnoscience researches show that traditional, local knowledge are not always infe-rior compared to scientific knowledge. As a product of longtime processes of adapta-tion traditional, local knowledge are quite suitable for the local people. Ethnosciences of the local peoples should thus be documented and kept to be combined and deve-loped together with scientific knowledge.

Ethnoecological study with its branches is beneficial not only for socio-cultural deve-lopments in certain localities where the researches are conducted. Decision makers, planners, and executors could learn as well as get various information from ethnoeco-logical study on how socio-cultural developments programmes are successfully carried out. Those studies are also scientifically important, especially for comparative studies on ecology and ethnoecology, as well as for studies on ecological problems in various parts of the world.

The branching out ethnoscience into several directions of study on natural environ-ment had made the results of ethnoscientific studies very relevant to "back-to-nature" movement and methodology. It contributes more data to support the programmes of the movement and different methodology to study natural environment

\section{References}

1. Albuquerque, U.P., L.V.F.C.da Cunha, R.F.P. de Lucena, R.R.N. Alves eds.). 2014. Methods and Techniques in Ethnobiology and Ethnoecology. New York, NY: Humana Press.

2. Acheson, J.M. 1972. "The territories of the Lobstermen”. Natural History 81: 60-69.

3. Acheson, J.M. 1977. "Technical skills and fishing success in the Maine lobster industry" dalam Material Culture: Styles, Organization and Dynamics of Technology, H. Lechtman dan R.Merrill (eds.). St.Paul: West Publications.

4. Ahimsa-Putra, H.S. 1985 "Etnosains dan Etnometodologi: Sebuah Perbandingan”. Masyarakat Indonesia. Th.XII (2): 103-133.

5. Ahimsa-Putra, H.S. 1997b “Air dan Sungai Ciliwung: Sebuah Kajian Etnoekologi”. Prisma 1,

Thn. XXVI: 51-72.

6. Ahimsa-Putra, H.S. 2002b. Etnosains dan Etnoteknologi: Wawasan Budaya Untuk Pengembangan Teknologi. Makalah seminar "Pembangunan Berwawasan Budaya".

7. Albuquerque, U.P., L.V.F. C. d. Cunha, R. F.P.d.Lucena, R.R.N. Alves (eds.). Methods and

Techniques in Ethnobiology and Ethnoecology. New York, NY: Humana Press.

8. Alves, R.R.N. and W.M.S.Souto. 2011. "Ethnozoology in Brazil: current status dan perspectives". Journal of Ethnobiology ann Ethnomedicine 7 (22): 1-18.

9. Alves, R.R.N. 2012. "Relationships between fauna and people and the role of ethnozoology in animal conservation". Ethnobiology and Conservation 1: 2.

10. Alves, R.R.N., dan W.M.S.Souto. 2015. "Ethnozoology: A Brief Introduction". Ethnobiology and Conservation 4 (1): 1-13.

11. Barrera-Bassols, N. dan J.A.Zinck. 2003. "Ethnopedology: a worldwide view on the soil knowledge of local people”. Geoderma 111 (3-4): 171-195.

12. Barrera-Bassols, N. dan V.M.Toledo. 2005. "Ethnoecology of the Yucatec Maya: Symbolism, Knowledge and Management of Natural Resources". Journal of Latin American Geography 4 (1): 9-41.

13. Begossi, A. 2006. "The ethnoecology of Caiçara metapopulations (Atlantic Forest, Brazil): ecological concepts and questions". Journal of Ethnobiology and Ethnomedicine 2 (40): 1-9

14. Begum, D. dan S.C.Nath. 2000. "Ethnobotanical Review of Medicinal Plants Used for Skin Diseases and Related Problems in Northeastern India”. Journal of Herbs, Spices \& Medicinal Plants 7 (3): 55-93. 
15. Bellon, M.R. 1991. "The ethnoecology of maize variety management: A case study from Mexico”. Human Ecology 19: 389-418.

16. Benarjee, G., K.Srikanth, G.Ramu dan K.N.Ramulu. 2010. "Ethnozoological study in a tropical wildlife sanctuary of Eturunagaram in the Warangal district, Andhra Pradesh”. Indian Journal of Traditional Knowledge 9 (4): 701-704.

17. Brinkmann, K., L.Samuel, S.Peth, A.Buerkert. 2018. “Ethnopedological knowledge and soil classification in SW Madagascar”. Geoderma Regional 14: 1-10.

18. Brush, S.B. 1980. "Potato Taxonomies in Andean Agriculture" dalam Indigenous Knowledge

Systems and Development, D.W.Brokensha et al (eds). Lanham: University Press of America.

19. Bryant, J. 1980. "Systems Theory, Survival, and the Back-to-Nature Movement". Technology and Culture 21 (2): 227-230.

20. Burling, R. 1969. "Linguistics and Ethnographic Description”. American Anthropologist 71: 817827.

21. Bussmann, R.W. dan D. Sharon. 2006. "Traditional medicinal plant use in Northern Peru: tracking two thousand years of healing culture". Journal of Ethnobiology and Ethnomedicine 2: 47.

22. Buthelezi-Dube, N.N., J.C.Hughes, P. Muchaonyerwa. 2018. "Indigenous soil classification in four villages of eastern South Africa". Geoderma 332: 84-99.

23. Capra, G.F., A.Ganga, A.Buondonno, E.Grilli, C.Gaviano, S.Vacca. 2015. 'Ethnopedology in the Study of Toponyms Connected to the Indigenous Knowledge on Soil Resource". PLOS ONE $\mid$ DOI: 10: 1371 .

24. Chakravorty et al. 2011. "Vertebrates used for medicinal purposes by members of the Nyishi and Galo tribes in Arunachal Pradesh (North-East India)". Journal of Ethnobiology and Ethnomedicine 7 (13) : 1-14

25. Chinsembu, K.C., J. Negumbo, M. Likando, A. Mbangu. 2014. "An ethnobotanical study of medicinal plants used to treat livestock diseases in Onayena and Katima Mulilo, Namibia”. South African Journal of Botany 94: 101-107.

26. Conklin, H.C. 1954. “An Ethnoecological Approach to Shifting Agriculture”. Transactions of the New York Academy of Sciences, $2^{\text {nd }}$ ser. vol 17: 133-142.

27. Cravalho, M.A. 1999. "Shameless Creatures: An Ethnozoology of the Amazon River Dolphin". Ethnology 38 (1): 47-58.

28. Durbin, M.A. 1966. "The Goals of Ethnoscience". Anthropological Linguistics 8 (8): 22-41.

29. Durbin, M.A. 1972. "Linguistic Models in Anthropology". Annual Review of Anthropology 1:Fleskens, L. and F. Jorritsma. 2010. " $A$ Behavioral Change Perspective of Maroon Soil
Fertility Management in Traditional Shifting Cultivation in Suriname”. Human Ecology 38 (2): 217-236

30. Fowler, C.S. 1977. "Ethnoecology" dalam Ecological Anthropology, D.L.Hardesty. New York: John Wiley and Sons.

31. Frake, C.O. 1962. "The Ethnographic Study of Cognitive Systems" dalam Anthropology and Human Behavior, T.Gladwin dan W.C.Sturtevant (eds.). Washington: Anthropological Society of Washington.

32. Fritz-Vietta, N.V.M., H.S.Tahirindraza, S.StollKleemann. 2017. 'Local people's knowledge with regard to land use activities in southwest Madagascar - Conceptual insights for sustainable land management". Journal of Environmental management 199 : 126-138.

33. García-Quijano, C. dan A. Pitchon. 2010. “Aquatic Ethnobiology”. Encyclopedia of Life: 16.

34. Gonzales, G.F. 2012. "Review Article Ethnobiology and Ethnopharmacology of Lepidium meyenii (Maca), a Plant from the Complementary and Alternative Medicine Vol. 2012: 1-10.

35. Goodenough, W.H. 1964a "Cultural Anthropology and Linguistics" dalam Language in Culture and Society, D.Hymes (ed.). New York: Harper and Row.

36. Goodenough, W.H. 1964b. "Introduction" dalam Explorations in Cultural Anthropology, W.H. Goodenough (ed.). New York: McGraw-Hill.

37. Goodenough, W.H. 1969a. "Frontiers of Cultural Anthropology: Social Organization”. Proceedings of the American Philosophical Society 113 (5): 3639.

38. Goodenough, W.H. 1970. Description and Comparison in Cultural Anthropology. Cambridge: Cambridge University Press

39. Gregori, T.R.de. 1982. "The Back-to-Nature Movement: Alternative Technologies and the Inversion of Reality". Technology and Culture $\mathbf{2 3}$ (2): 214-217.

40. Haenn, N. 1999. "The power of environmental knowledge: Ethnoecology and environmental conflicts in Mexican conservation". Human Ecology 27(3): 477-491.

41. Henderson, J. dan J.P.Harrington. 1914. Ethnozoology of the Tewa Indians. Bulletin 56. Bureau of American Ethnology. Smithsonian Institution.

42. Hermans, M., A. Akoègninou and L.J.G. van der Maesen. 2004. "Medicinal Plants Used to Treat Malaria in Southern Benin”. Economic Botany, 58 Supplement: S239-S252.

43. Johnson, L. 2000. "'A place that's good,' Gitksan landscape perception and ethnoecogy". Human Ecology 28 (2): 301-325. 
44. Johnsn, L. 2008. "Plants and habitats - A consideration of Dene ethnoecology in northwestern Canada”. Botany 86 (2): 146-156.

45. Johnson, L. and I. Davidson-Hunt. 2011. "Ethnoecology and Landscapes" dalam

Ethnobiology, E. N. Anderson, D. Pearsall, E. Hunn, N. Turner (eds.). Hoboken, NJ:John Wiley and Sons.

46. Jorgensen, J.G. 1979. “Cross-Cultural Comparisons". Annual Review of Anthropology 8: $309-331$.

47. Kala, C.P., P.P.Dhyani and B.S.Sajwan. 2006. "Developing the medicinal plants sector in northern India: challenges and opportunities". Journal of Ethnobiology and Ethnomedicine 2:32: $1-15$

48. Kato, D. dan Gopi GV. 2009. "Ethnozoology of Galo tribe with special reference to edible insects in Arunacha Pradesh". Indian Journal of Traditional Knowledge 8 (1): 81-83.

49. Keesing, R.M. 1972. "Paradigms Lost: The New Ethnography and the New Linguistics". Southwestern Journal of Antrhopology 28 (4): 299-332.

50. Kendie, F.A. S.A.Mekuriaw and M.A.Dagnew. 2018. "Ethnozoological study of traditional medicinal appreciation of animals and their products among the indige-nous people of Metema Woreda, North-Western Ethiopia". Journal of Ethnobio-logy and Ethnomedicine 14: 37

51. Kindscher,K., Q. Long, S. Corbett, K. Bosnak, H.Loring, M. Cohen and B.N. TimmerMann. 2012. "The Ethnobotany and Ethnopharmacology of Wild Tomatillos, Physalis longifolia Nutt., and Related Physalis Species: A Review”. Economic Botany 66 (3): 298-310.

52. Kissing, L., A.Pimentel and M.Valido. 2009. "Participatory Soil Improvement: A Cuban

Case Study in Fertility Management”. Cultivos Tropicales 30 (2): 43-52.

53. Koné, W.M. dan K.K. Atindehou. 2008. "Ethnobotanical inventory of medicinal plants Used in traditional veterinary medicine in Northern Côte d'Ivoire (West Africa)'”. South African Journal of Botany 74 (1): 76-84.

54. Linton, R. 1945. The Cultural Background of Personality. New York: Appleton Century Croft.

55. Lohani, U. 2010. "Man-animal relationships in Central Nepal". Journal of Ethnobiology and Ethnomedicine 6 (31): 1-13.

56. Lohani, U. 2011. "Eroding Ethnozoological Knowledge among Magars in Central Nepal". Indian Journal of Traditional Knowledge 10 (3): 466-473.

57. Lohani, U. 2012. "Zootherapeutic Knowledge of Two Ethnic Population from Central Nepal”. Ethno Med 6 (1): 45-53.

58. Lohani, U., K.Rajbhandari dan K.Shakuntala. 2008. "Need for a systematic ethnozoo logical studies in the conservation of ancient knowledge system of Nepal a re view". Indian Journal of Traditional Knowledge 7 (4): 634-637.

59. Ludwig, D. dan C. El-Hani. 2019. "Philosophy of ethnobiology: understanding knowledge integration and its limitations". Journal of ethnobiology en prensa 1-29.

60. Martin, G. 2001. "Ethnobiology and Ethnoecology”. Encyclopedia of Biodiversity. Elsevier Inc.

61. Matuk, F.A., C.E.G.R.Schaefer, F.N.B.Simas, TT.C.Pereira, D.F.Gjorup and F.M.G. Coelho. 2017. "Ethnopedology of a Quilombola Community in Minas Gerais: Soils, Landscape, and Land Evaluation". Revista Brasileira de Ciencia do Solo 41: 1-19.

62. Metzger, D.G. dan G.E. Williams. 1966. "Some Procedures and Results in the Study of Native Categories: Tzeltal "Firewood"', American Anthropologist 68 (2) Part 1: 389-407.

63. Moran, E. and D.Posey. 2019. "Indigenous Ecological Knowledge and Development of the Amazon". Routledge: 225-257.

64. Motti, R., V. Antignani and M. Idolo. 2009. "Traditional Plant Use in the Phlegraean Fields Regional Park (Campania, Southern Italy) '”. Human Ecology 37 (6): 775-782.

65. Nath, A.J., R.Lal, A.K.Das. 2015. "Ethnopedology and soil quality of bamboo (Bambusa sp) based agroforestry system". Science of the Total Environment 521-522:372-379.

66. Obeyesekere, G. 1977. "The theory and practice of psychological medicine in the Ayu vedic tradition". Culture, Medicine and Psychiatry 1: $155-181$.

67. Olson, E. 2013. “Anthropology and Traditional Ecological Knowledge: A Summary of

Quantitative Approaches to Traditional Knowledge, Market Participation, and

Conservation". Culture, Agriculture, Food and Environment 35 (2): 140-151.

68. Pauli, N., L.K. Abbott, S. Negrete-Yankelevich dan P. Andrés. 2016. 'Farmers' know-ledge and use of soil fauna in agriculture a worldwide review”. Ecology and Society 21 (3): 19

69. Pedroso-Júnior, N. dan M. Sato. 2005.

"Ethnoecology and conservation in protect natural areas: incorporating local knowledge in Superagui National Park management”. Brazilian journal of biology (Revista brasleira de biologia) 65 (1):117-127

70. Peña-Venegas, C.P., T. J. Stomph, G. Verschoor, J. A. Echeverri, and P. C. Struik.2016.

"Classification and Use of Natural and Anthropogenic Soils by Indigenous Communities of the Upper Amazon Region of Colombia”. Human Ecology 44: 1-15. 
71. Perchonock, N.and O.Werner. 1969. "Navaho Systems of Classification: Some Implications for Ethnoscience”. Ethnology 8 (3): 229-242.

72. Pieroni, A. M.E. Giusti, dan C.L. Quave. 2011. "Cross-Cultural Ethnobiology in the Western Balkans: Medical Ethnobotany and Ethnozoology Among Albanians and Serbs in the Pester Plateau, Sandžak, South-Western Serbia”. Human Ecology 39: 333-349.

73. Posey, D., J.Frechione, J.Eddins J, et al. 1984. "Ethnoecology as Applied Anthropology in Amazonian Development". Human Organization 43 (2): 95-107.

74. Rainey, S.J. 2005. "Folk Classification and Capability Assessment of Soils in two Highland Guatemalan Municipios". Journal of Latin American Geography 4 (1): 77-106.

75. Rangel-Landa, S. et al. 2016. "Ixcatec ethnoecology: plant management and biocultural heritage in Oaxaca, Mexico". Journal of Ethnobiology and Ethnomedicine 12: 30.

76. Raymond, J. 2001. "Back to Nature". The Science Teacher 68 (4): 62-64.

77. Rose, J.L., E.Ö. Özünel and B.C. Bennett. 2013. "Ethnobotanical Remedies for Acute Diarrhea in Central Anatolian Villages”. Economic Botany 67 (2): 137-146.

78. Rupununi, S. and T.Henfrey. 2002. "Ethnoecology , Resource Use, Conservation And Development In A Wapishana Community In the by". Interactions (March): 296.

79. Samant, S.S. and U. Dhar. "Diversity, endemism and economic potential of wild edible plants of Indian Himalaya". International Journal of Sustainable Development \& World Ecology, 4:3, 179-191. (1997).

80. Silvano, R.A.M. and A.Begossi. "Local knowledge on a cosmopolitan fish: Ethnoecology of Pomatomus saltatrix (Pomatomidae) in Brazil and Australia”. Fish-eries Research 71 (1): 43-59. (2005)

81. Skingle, R.C. "Some medical herbs used by the natives of New Guinea”. Mankind 7: 223-225. (1970).

82. Souza, S.P. dan A.Begossi. "Whales, dolphins or fishes? The ethnotaxonomy of cetaceans in São Sebastião, Brazil’. Journal of Ethnobiology and Ethnomedicine 3:9: 1-15. (2007).

83. Spradley. The Ethnographic Interview. New York: Holt, Rinehart and Winston. (1979).

84. Spradley. Participation Observation. New York: Holt, Rinehart and Winston. (1979).

85. Sturtevant, W.C. "Studies in Ethnoscience" dalam Transcultural Studies in Cognition,

A.K.Romney dan R.G.A.D'Andrade (eds.) American Anthropologist Special Publication 66 (3). Part.2. (1964).
86. Toledo, V. "What is Ethnoecology? Origins, Scope, and Implications of a Rising Discipline”. Etnoecologia 1(1): 5-21. (1992).

87. Trusler, S. and L.M. Johnson. "Berry Patch” As a Kind of Place - the Ethnoecology of Black Huckleberry in Northwestern Canada". Human Ecology 36: 553-568. (2008).

88. Tyler, S.A. "Introduction" dalam Cognitive Anthropology, S.A.Tyler (ed.). New York: Holt, Rinehart and Winston. (1969).

89. Utomo, A.P., M.H.I.Al Muhdhar, I.Syamsuri, S.E.Indriwati. 2018. "Local Ecological Knowledge in Angklung Paglak of Using Community of Banyuwangi, Indonesia”. Applied Ecology and Environmental Research 16 (3): 3215-3228.

90. Vats, R. and S.Thomas. 2015. "A study on the use of animals as traditional medicine by Sukuma Tribe of Busega District in North-Western Tanzania". Journal of Ethnobiology and Ethnomedicine 11 (38):

91. Watts, P., K.Koutouki, S.Booth et al. 2017. "Inuit food security in Canada: arctic marine ethnoecology". Food Security 9: 421-440.

92. Werner, O. 1969. "The Basic Assumptions of Ethnoscience". Semiotica 1 (3): 328-338.

93. Werner, O. 1972. "Ethnoscience". Annual Review of Anthropology 1: 271-308.

94. Werner, O. dan J.Fenton 1970 "Method and Theory in Ethnoscience or Ethnoepiste mology" dalam Handbook of Method in Cultural Anthropology, R.Naroll dan R. Cohen (eds.). New York: Natural History Press.

95. Williams, B.J. dan C.A. Ortiz-Solorio. 1981. "Middle American Folk Soil Taxonomy" Annals of the Association of American Geographers 71 (3): 335-358.

96. WinklerPrins, A.M.G.A. dan E. Barrios. "Ethnopedology along the Amazon andOrinoco Rivers: A Convergence of Knowledge and Practice”. Revista Geográfica 142: 111-129. (2007). 